\title{
Mandibular gland component analysis in the head extracts of Apis cerana and Apis nigrocincta
}

\author{
Christopher I. KeEling ${ }^{\mathrm{a} *}$, Gard W. Otis ${ }^{\mathrm{b}}$, Soesilawati Hadisoesilo ${ }^{\mathrm{c}}$, \\ Keith N. SLESSOR ${ }^{a}$ \\ ${ }^{a}$ Department of Chemistry, Simon Fraser University, 8888 University Drive, \\ Burnaby, British Columbia, V5A 1S6, Canada \\ ${ }^{\mathrm{b}}$ Department of Environmental Biology, University of Guelph, Guelph, \\ Ontario, N1G 2W1, Canada \\ ${ }^{\mathrm{c}}$ Pusat Litbang Hutan dan Konservasi Alam, Jl. Gunung Batu No. 5, Bogor, Indonesia
}

(Received 5 September 2000; revised 26 February 2001; accepted 28 February 2001)

\begin{abstract}
Head extracts of workers and mated queens of the closely related species of Apis cerana and A. nigrocincta from Sulawesi, Indonesia were quantitatively analyzed by gas chromatographymass spectrometry for several mandibular gland components. The amounts of many compounds were significantly different between species for both queens and workers. Quantities of 10 of the 16 compounds quantified in queen bees differed significantly between the two species. Of the three known mandibular gland retinue pheromone components in $A$. cerana queens $[(E)$-9-oxodec-2-enoic acid (9-ODA), (E)-9-hydroxydec-2-enoic acid (9-HDA), and methyl $p$-hydroxybenzoate (HOB)], the amounts of 9-HDA and HOB were significantly different between species. Quantities of 6 of the 11 compounds quantified in worker bees differed significantly between the two species. This quantitative analysis supports the hypothesis that $A$. cerana and $A$. nigrocincta are indeed separate species.
\end{abstract}

Apis cerana / Apis nigrocincta / honey bee / mandibular gland / pheromone

\section{INTRODUCTION}

It has long been known that cavity-nesting honey bees inhabit Sulawesi and the surrounding islands of Indonesia. Maa (1953) recognized a unique species of honey bee from "The Celebes" (Sulawesi), Apis nigrocincta Fabr. Smith, 1861. However, most reports about honey bees from this region have presumed that the cavity-nesting bees there are forms of Apis cerana Fabr., the common hive bee that ranges over

* Correspondence and reprints

E-mail: ckeeling @ sfu.ca 
most of Asia. Recently two distinct populations of cavity-nesting honey bees were verified in Sulawesi (Hadisoesilo et al., 1995). Although sympatric in at least two areas of Sulawesi, they do not appear to hybridize, suggesting they are distinct species.

Morphometric analyses have indicated that the smaller, darker morph corresponds to A. cerana and the larger morph with yellowish clypeus and legs corresponds to A. nigrocincta (Hadisoesilo et al., 1995; Damus and Otis, 1997). These species also have different drone cell cappings. It is well documented that $A$. cerana drone cells are sealed with a wax capping underlain by a hard conical cocoon structure that contains a central pore (Ruttner, 1988; Boecking et al., 1999). In contrast, sealed A. nigrocincta drone cells have only a thin wax capping and lack the hardened cap with pore (Hadisoesilo and Otis, 1998). The timing of the mating flights also differs between the two species, with flights of $A$. cerana drones preceding and only slightly overlapping those of $A$. nigrocincta drones (Hadisoesilo and Otis, 1996), thereby affecting almost complete reproductive isolation between the populations. These differences indicate that they are two distinct species and that we might expect to find other differences.

The chemical composition of the mandibular glands of both honey bee queens and workers have previously been analyzed as a method to compare different species (Plettner et al., 1997). In the queen, these glands produce pheromone messages that elicit the retinue of workers, attract drones on mating flights, and are believed to control several aspects of colony functioning (Winston and Slessor, 1998). The functions of the components in the worker mandibular glands are attributed to food preservation and larval nutrition (Winston, 1987).

In A. mellifera L., both female castes produce distinctive blends of compounds in their mandibular glands with functionalized aliphatic acids predominating in both castes
(Plettner et al., 1996; Plettner et al., 1998). In mated queens, compounds functionalized at the penultimate $(\omega-1)$ position of the chain $[(E)$-9-oxodec-2-enoic acid (9-ODA) and the two enantiomers of $(E)$-9-hydroxydec-2enoic acid (9-HDA)] predominate. In workers, compounds functionalized at the terminal $(\omega)$ position [10-hydroxydecanoic acid (10-HDAA) and (E)-10-hydroxydec-2-enoic acid (10-HDA)] predominate. The mandibular glands of A. mellifera queens also produce several aromatic compounds of which methyl $p$-hydroxybenzoate (HOB) and 4-hydroxy-3-methoxyphenylethanol (HVA) account for the retinue attraction of the queen mandibular glands when combined with 9-ODA and 9-HDA (Slessor et al., 1988). These compounds comprise the queen mandibular pheromone for retinue attraction in A. mellifera but do not account for all of the retinue attraction or chemical communication attributed to the queen (Slessor et al., 1998; Winston and Slessor, 1998; Keeling et al., 2000a).

Unfortunately, the queen mandibular pheromone of $A$. cerana has not been so well characterized. It is known that HVA is absent from queen mandibular glands and does not increase retinue attraction of $A$. cerana workers when added to the other three compounds (Plettner et al., 1997). There has been no analysis of the mandibular gland composition of $A$. nigrocincta. In this study, we quantitatively analyzed head extracts for several mandibular gland components to reveal any differences between the mandibular gland compositions of these closely related species.

The compounds quantified in this study include those previously quantified in other studies (Plettner et al., 1997; Keeling et al., 2000b) as well as some of the compounds recently identified in $A$. mellifera queen mandibular glands (Engels et al., 1997; Matsuyama et al., 1997; Keeling and Slessor, unpublished observations). Apart from those mentioned above, the compounds quantified have not been reported to be 
pheromone components in any honey bee species and may only represent differences in biosynthetic pathways of the different species and castes of honey bees. Most of the aliphatic acids are biosynthetically linked to the major queen and worker produced acids (Plettner et al., 1996; Plettner et al., 1998). The biosynthetic pathways of the aromatic compounds HOB and HVA have not been reported but the other aromatic compounds quantified in this study are potentially linked biosynthetically to these pheromone components. As we learn more about the mandibular gland biochemistry of honey bees and test compounds for biological activity in honey bee species other than A. mellifera, some of these compounds may be of importance in Apis semiochemistry.

\section{MATERIALS AND METHODS}

\subsection{Collection of specimens}

Bees from both wild and managed colonies were collected in September and October of 1998 in Sulawesi, Indonesia. A. nigrocincta were collected from Bobo and Rahmat, near Palu, in Central Sulawesi and Air Mandidi and Kauditan, near Manado, in Northern Sulawesi. A. cerana were collected from Bobo, Rahmat, and Lolu, in Central Sulawesi. A forager, queen, and nurse bee were collected from each colony. The forager was collected first as she exited the colony entrance. The colony was then opened and the queen located. All queens were mated and actively laying eggs (brood of all stages was present in each colony). A bee on the brood comb was taken as a nurse bee. We could not dissect the mandibular glands in the field so the bees were decapitated with a razor blade (different blades for each caste/species). The heads were placed individually in glass vials $(2 \mathrm{~mL})$ pre-loaded with methanol $(200 \mu \mathrm{L})$ containing undec10-enoic acid (16 $\mu \mathrm{g}$, Matheson, Coleman and Bell, Norwood OH USA) as an internal standard and shipped to Simon Fraser
University. Upon arrival, samples were stored at $-20{ }^{\circ} \mathrm{C}$ until extracted.

\subsection{Extraction and analysis}

Although all compounds analyzed originate within the mandibular glands, the whole head was extracted because the analytes are leached from the intact mandibular glands into the rest of the head by the shipping solvent (Plettner et al., 1997). Bee heads were crushed in the shipping solvent and extracted with additional methanol. Extracts were centrifuged briefly to remove solids and then stored at $-20^{\circ} \mathrm{C}$ until analyzed.

Extracts were then analyzed as their trimethylsilyl derivatives by gas chromatography-mass spectrometry in a manner similar to Keeling et al. (2000b). Fifteen of the compounds quantified were obtained commercially as follows: 3-hydroxyoctanoic acid (3-HOAA), methyl $p$-hydroxybenzoate (HOB), 3-hydroxydecanoic acid (3-HDAA), 4-hydroxy-3-methoxyphenylethanol (HVA), 10-hydroxydecanoic acid (10-HDAA) $(E)$-coniferyl alcohol, $(E)$-ferulic acid, 4-hydroxy-3-methoxyacetophenone, decanedioic acid (C10:0 DA), and (E)-4-hydroxycinnamic acid from Sigma-Aldrich Canada Inc. (Oakville, ON, Canada); 4-hydroxyacetophenone and 4-hydroxybenzoic acid from Eastman Kodak Co. (Rochester NY USA); (E)-9-oxodec-2-enoic acid (9-ODA), (E)-9-hydroxydec-2-enoic acid (9-HDA), and $(E)$-10-hydroxydec-2-enoic acid (10-HDA) from PheroTech Inc. (Delta, BC, Canada). The remaining four compounds quantified were synthesized as follows: 8-hydroxyoctanoic acid (8-HOAA) by partial oxidation of 1,8-octanediol (Plettner, 1995), dihydroconiferyl alcohol by hydroboration-oxidation of eugenol (Fieser and Fieser, 1967), dihydroferulic acid by hydrogenation of $(E)$-ferulic acid (Fieser and Fieser, 1967), and (E)-dec-2-enedioic acid (C10:1 DA) by oxidation of 10-HDA (Plettner, 1995). 
Eleven standard solutions containing trimethylsilyl derivatives of the internal standard and all analytes were used to calibrate the response of the instrument with respect to the internal standard over a 1024-fold range of concentration for each analyte. We used the mass spectrometer's software capability to integrate peaks over specific masses. Masses were chosen for each analyte based on the fragmentation patterns of the trimethylsilyl derivatives [typically $\mathrm{M}^{+}$or $\left.(\mathrm{M}-15)^{+}\right]$and the absence of adjacent peaks with similar masses. The masses for integration and the retention indices (van den Dool and Kratz, 1963) for these derivatives on the DB-5ms column were as follows (mass, retention index): undec-10-enoic acid $(241,1544), 3$-HOAA $(289,1467)$, 4-hydroxyacetophenone (193, 1468), HOB $(193,1490), 8$-HOAA $(289,1614)$, 4-hydroxy-3-methoxyacetophenone (238, 1614), 4-hydroxybenzoic acid $(267,1622)$, 3-HDAA $(317,1647)$, HVA $(312,1701)$, 9-ODA $(241,1701)$, 9-HDA $(315,1785)$, 10-HDAA $(317,1805)$, dihydroconiferyl alcohol $(326,1811), 10$-HDA $(315,1858)$, C10:0 DA $(331,1888)$, dihydroferulic acid (325, 1888), (E)-coniferyl alcohol (324, 1933), (E)-4-hydroxycinnamic acid (308, 1934), C10:1 DA $(329,1937)$, and $(E)$-ferulic acid $(338,2085)$. The retention indices and MS fragmentation patterns of the synthetic analytes matched those found in the extract. Quantities reported in text are mean \pm SE. To meet the requirements of normality and equal variances for parametric testing, all measurements were transformed by $x^{\prime}=(x+0.5)^{0.5}$ before statistical analysis with JMP software (SAS Institute Inc. 1996)

\section{RESULTS}

\subsection{Queens}

The two species were significantly different in 10 of the 16 compounds detected and quantified in the queens (Tab. I). Most significantly, $A$. cerana queens had over four times more HOB than did $A$. nigrocincta queens. A. cerana queens had significantly more $\omega$-functionalized acids than A. nigrocincta for all compounds quantified (8-HOAA, 10-HDA, 10-HDAA, C10:0 DA, and C10:1 DA) except 8-HOAA. Of the two ( $\omega-1)$-functionalized acids (9-ODA and 9-HDA), A. nigrocincta had significantly more 9-HDA than did A. cerana. As a result, the 10-HDA/9-HDA ratios, an indication of the weighting of the two parallel $\omega$ and $\omega-1$ biosynthetic pathways, were also significantly different $(0.53 \pm 0.03$ and $0.22 \pm$ 0.02 for $A$. cerana and $A$. nigrocincta respectively, $t$-test $p<0.0001)$. The following aromatic compounds that are found in A. mellifera queens could not be detected in A. cerana or A. nigrocincta queens: HVA, dihydroconiferyl alcohol, and $(E)$-coniferyl alcohol.

\subsection{Workers}

When nurse and forager workers were pooled together for each species, workers of the two species were significantly different in 6 of the 11 compounds detected and quantified in workers (Tab. II). A. nigrocincta workers had significantly more $\omega$-functionalized acids than did A. cerana workers for all compounds quantified (8-HOAA, 10-HDA, 10-HDAA, C10:0 DA, and C10:1 DA) except 8-HOAA. The quantities of the ( $\omega$-1)-functionalized acids (9-ODA and 9-HDA) were not significantly different between species but the 10-HDA/9HDA ratios were $(5.39 \pm 0.86$ and $14.77 \pm$ 2.29 for $A$. cerana and $A$. nigrocincta respectively, $t$-test $p<0.0001$ ). These observations were the opposite of those seen in the queens. HOB, 4-hydroxy-3-methoxyacetophenone, dihydroferulic acid, $(E)$-4-hydroxycinnamic acid, $(E)$-ferulic acid, HVA, dihydroconiferyl alcohol, and $(E)$-coniferyl alcohol were not detected in any of the workers.

There were also differences between foragers and nurse bees (Tab. III). Most of the 
Table I. Quantitative analysis of mandibular gland components in queen head extracts. Compounds listed in their order of elution as trimethylsilyl derivatives from the DB-5ms GC column.

\begin{tabular}{|c|c|c|c|}
\hline & \multicolumn{2}{|c|}{$\mu \mathrm{g} /$ queen $($ mean $\pm \mathrm{SE})$} & \multirow[t]{2}{*}{$t$-test ${ }^{\mathrm{a}}$} \\
\hline & A. cerana & A. nigrocincta & \\
\hline Compound & $(n=14)$ & $(n=12)$ & \\
\hline 3-HOAA & $0.87 \pm 0.04$ & $1.09 \pm 0.25$ & \\
\hline 4-hydroxyacetophenone & $0.29 \pm 0.04$ & $0.10 \pm 0.01$ & $* * *$ \\
\hline $\mathrm{HOB}$ & $43.6 \pm 5.5$ & $9.26 \pm 2.98$ & $* * * *$ \\
\hline 8-HOAA & $12.9 \pm 1.2$ & $17.6 \pm 4.2$ & \\
\hline 4-hydroxy-3-methoxyacetophenone & $16.0 \pm 1.5$ & $6.85 \pm 1.63$ & *** \\
\hline 4-hydroxybenzoic acid & $2.60 \pm 0.39$ & $4.83 \pm 0.70$ & $* *$ \\
\hline 3-HDAA & $0.44 \pm 0.03$ & $0.66 \pm 0.18$ & \\
\hline 9-ODA & $110 \pm 4$ & $116 \pm 7$ & \\
\hline 9-HDA & $61.5 \pm 3.1$ & $106 \pm 8$ & $* * * *$ \\
\hline 10-HDAA & $4.22 \pm 0.42$ & $2.74 \pm 0.23$ & $* *$ \\
\hline 10-HDA & $32.7 \pm 3.0$ & $23.1 \pm 2.4$ & $*$ \\
\hline C10:0 DA & $10.5 \pm 1.1$ & $6.02 \pm 0.73$ & $* *$ \\
\hline dihydroferulic acid & $0.06 \pm 0.01$ & $0.18 \pm 0.11$ & \\
\hline (E)-4-hydroxycinnamic acid & $0.14 \pm 0.01$ & $0.27 \pm 0.07$ & $*$ \\
\hline C10:1 DA & $46.0 \pm 3.3$ & $29.1 \pm 3.4$ & ** \\
\hline (E)-ferulic acid & $0.25 \pm 0.02$ & $0.24 \pm 0.05$ & \\
\hline
\end{tabular}

${ }^{\mathrm{a}} t$-test of $(\mathrm{x}+0.5)^{0.5}$ transformed data, $*=(p<0.05), * *=(p<0.01), * * *=(p<0.001)$, and $* * * *=(p<0.0001)$.

Table II. Quantitative analysis of mandibular gland components in worker head extracts. Compounds listed in their order of elution as trimethylsilyl derivatives from the DB-5ms GC column.

\begin{tabular}{|c|c|c|c|}
\hline & \multicolumn{2}{|c|}{$\mu \mathrm{g} /$ worker $($ mean $\pm \mathrm{SE})$} & \multirow[t]{2}{*}{$t$-test ${ }^{\mathrm{a}}$} \\
\hline & A. cerana & A. nigrocincta & \\
\hline Compound & $(n=24)$ & $(n=21)$ & \\
\hline 3-HOAA & $5.76 \pm 1.00$ & $8.81 \pm 1.15$ & \\
\hline 4-hydroxyacetophenone & $0.09 \pm 0.01$ & $0.12 \pm 0.01$ & \\
\hline 8-HOAA & $6.19 \pm 1.01$ & $7.97 \pm 1.49$ & \\
\hline 4-hydroxybenzoic acid & $0.04 \pm 0.00$ & $0.07 \pm 0.01$ & $* * *$ \\
\hline 3-HDAA & $0.33 \pm 0.04$ & $0.62 \pm 0.09$ & $* *$ \\
\hline 9-ODA & $0.21 \pm 0.03$ & $0.16 \pm 0.03$ & \\
\hline 9-HDA & $1.00 \pm 0.25$ & $0.75 \pm 0.19$ & \\
\hline 10-HDAA & $2.64 \pm 0.42$ & $4.75 \pm 0.78$ & $*$ \\
\hline 10-HDA & $3.55 \pm 0.80$ & $9.42 \pm 1.77$ & $* *$ \\
\hline C10:0 DA & $1.92 \pm 0.32$ & $3.86 \pm 0.62$ & $*$ \\
\hline C10:1 DA & $3.22 \pm 0.59$ & $6.48 \pm 0.93$ & $* *$ \\
\hline
\end{tabular}

${ }^{\mathrm{a}} t$-test of $(\mathrm{x}+0.5)^{0.5}$ transformed data, $*=(p<0.05),{ }^{* *}=(p<0.01), * * *=(p<0.001)$. 
Table III. Quantitative analysis of mandibular gland components in forager and nurse bee head extracts. Compounds listed in their order of elution as trimethylsilyl derivatives from the DB-5ms GC column.

\begin{tabular}{|c|c|c|c|c|}
\hline \multirow[b]{3}{*}{ Compound } & \multicolumn{4}{|c|}{$\mu \mathrm{g} /$ worker $(\text { mean } \pm \mathrm{SE})^{*}$} \\
\hline & \multicolumn{2}{|c|}{ Foragers } & \multicolumn{2}{|c|}{ Nurses } \\
\hline & $\begin{array}{l}\text { A. cerana } \\
(n=13)\end{array}$ & $\begin{array}{l}\text { A. nigrocincta } \\
(n=14)\end{array}$ & $\begin{array}{c}\text { A. cerana } \\
(n=11)\end{array}$ & $\begin{array}{l}\text { A. } \\
(n=7)\end{array}$ \\
\hline 3-HOAA & $8.30 \pm 1.29 \mathrm{~b}$ & $9.55 \pm 1.18 b$ & $2.75 \pm 0.99 \mathrm{a}$ & $7.32 \pm 2.58 \mathrm{ab}$ \\
\hline 4-hydroxyacetophenone & $0.13 \pm 0.02 b$ & $0.14 \pm 0.02 b$ & $0.04 \pm 0.01 \mathrm{a}$ & $0.09 \pm 0.03 \mathrm{ab}$ \\
\hline 8-HOAA & $5.25 \pm 1.25 \mathrm{a}$ & $7.20 \pm 1.86 \mathrm{a}$ & $7.30 \pm 1.64 \mathrm{a}$ & $9.51 \pm 2.55 \mathrm{a}$ \\
\hline 4-hydroxybenzoic acid & $0.04 \pm 0.00 \mathrm{a}$ & $0.07 \pm 0.01 \mathrm{~b}$ & $0.05 \pm 0.01 \mathrm{ab}$ & $0.07 \pm 0.01 \mathrm{~b}$ \\
\hline 3-HDAA & $0.28 \pm 0.04 \mathrm{a}$ & $0.55 \pm 0.11 \mathrm{ab}$ & $0.38 \pm 0.08 \mathrm{ab}$ & $0.76 \pm 0.16 b$ \\
\hline 9-ODA & $0.26 \pm 0.05 \mathrm{~b}$ & $0.10 \pm 0.02 \mathrm{a}$ & $0.14 \pm 0.03 \mathrm{ab}$ & $0.27 \pm 0.07 \mathrm{~b}$ \\
\hline 9-HDA & $0.35 \pm 0.13 \mathrm{a}$ & $0.48 \pm 0.15 \mathrm{a}$ & $1.77 \pm 0.43 \mathrm{~b}$ & $1.28 \pm 0.43 \mathrm{ab}$ \\
\hline 10-HDAA & $1.24 \pm 0.31 \mathrm{a}$ & $4.23 \pm 0.91 b$ & $4.30 \pm 0.49 \mathrm{~b}$ & $5.80 \pm 1.52 \mathrm{~b}$ \\
\hline 10-HDA & $1.64 \pm 0.51 \mathrm{a}$ & $7.51 \pm 2.11 \mathrm{~b}$ & $5.81 \pm 1.37 \mathrm{ab}$ & $13.2 \pm 2.9 \mathrm{~b}$ \\
\hline C10:0 DA & $1.21 \pm 0.27 \mathrm{a}$ & $3.25 \pm 0.76 a b$ & $2.77 \pm 0.54 \mathrm{ab}$ & $5.08 \pm 0.99 \mathrm{~b}$ \\
\hline C10:1 DA & $2.06 \pm 0.57 \mathrm{a}$ & $5.51 \pm 1.11 \mathrm{~b}$ & $4.58 \pm 0.98 \mathrm{ab}$ & $8.42 \pm 1.52 \mathrm{~b}$ \\
\hline
\end{tabular}

* Means in each row followed by the same letter are not significantly different using Tukey-Kramer HSD of $(x+0.5)^{0.5}$ transformed data $(p<0.05)$. 
compounds quantified were more abundant in nurse bees than foragers. A. cerana foragers were significantly different from A. cerana nurses in 4 of the 11 compounds quantified whereas only 9-ODA was significantly different between $A$. nigrocincta foragers and nurses. The nurses were not significantly different between species for any compound quantified. A. nigrocincta foragers had significantly more of 5 of the 11 compounds quantified than A. cerana foragers.

\subsection{Differences between queens and workers}

Queens had larger amounts of all aromatic compounds than did workers. The following aromatic compounds appeared queen-specific for both species: HOB, 4-hydroxy-3-methoxyacetophenone, dihydroferulic acid, $(E)$-4-hydroxycinnamic acid, and $(E)$-ferulic acid. As in A. mellifera, queens had greater quantities of ( $\omega$-1)-functionalized acids compared to workers but unlike A. mellifera, queens also tended to have greater quantities of $\omega$-functionalized acids than workers.

\section{DISCUSSION}

These two species of honey bees were clearly distinguishable by the differences in the mandibular gland components found in their head extracts. Most obvious for queens were the differences in quantities of $\mathrm{HOB}$ and 9-HDA. A. cerana queens contained more than four times the HOB and about one half the 9-HDA of A. nigrocincta queens. In addition, $A$. cerana queens had relatively more $\omega$-functionalized acids and correspondingly less of the ( $\omega$-1)-functionalized acid 9-HDA than $A$. nigrocincta queens. The quantities of several aromatic compounds also differed significantly between species. However, when viewed with respect to chemical similarities, it is notable that queens of these closely related species share every quantified compound. The quantities of 9-ODA in particular, believed to be the major queen sex pheromone component of these and most other honey bee species (Koeniger et al., 1999) are identical. This may allow interspecific attraction of drones during their slightly overlapping mating times. However, drones may discriminate between queens of different species using additional, presently unidentified, chemical cues produced by queens. An investigation of the cross-attraction of drones to queen extracts of both species is needed to establish reproductive isolation based on differences in the sex pheromone. The A. cerana queens were dissimilar in the quantities of several compounds to the newly mated $A$. cerana queens from Malaysia previously analyzed (Plettner et al., 1997). This suggests that, like morphological variation, intra-specific chemical variation is high throughout $A$. cerana's large geographical range. Such variation is also apparent between the different races of A. mellifera (Crewe and Velthuis, 1980; Pankiw et al., 1996).

Most of the aromatic compounds quantified were queen-specific. In the mandibular glands of A. mellifera queens, HVA, dihydroconiferyl alcohol, and $(E)$-coniferyl alcohol are easily detected but 4-hydroxy-3methoxyacetophenone can be found in only trace amounts (Keeling and Slessor, unpublished observations). Of these compounds, only 4-hydroxy-3-methoxyacetophenone was detected in the head extracts of $A$. cerana and $A$. nigrocincta queens. As these compounds are structurally related, it is tempting to speculate that (a) they share a common biosynthetic pathway and (b) A. mellifera differ from A. cerana and $A$. nigrocincta by species-specific differences in this pathway. A better understanding of the biosyntheses of the aromatic compounds in the mandibular glands is needed.

The workers of these two species were also significantly different. A. nigrocincta 
workers had greater quantities of all the $\omega$-functionalized acids than $A$. cerana workers. Nurse bees also tended to have greater quantities than did foragers. Unfortunately, our understanding of the functions of these compounds is rudimentary.

More than half of the compounds investigated in queens and workers showed significant quantitative differences between the two species. This quantitative analysis supports the hypothesis that $A$. cerana and $A$. nigrocincta are indeed separate species. In addition, this analysis of the mandibular gland components contributes to a better understanding of the semiochemistry of this important gland in Apis.

\section{ACKNOWLEDGMENTS}

We thank H.T. Ngo for doing the extractions. G.W.O. and S.H. used personal funds to cover expenses related to field work in Sulawesi; their involvement with a conservation project of The Nature Conservancy funded by the Biodiversity Conservation Network covered travel expenses. We also appreciate the support of Simon Fraser University for a Graduate Fellowship to CIK and the Natural Sciences and Engineering Research Council of Canada to KNS.

Résumé - Analyse des composés de la glande mandibulaire dans les extraits de tête d'Apis cerana et Apis nigrocincta. Au Sulawesi, Indonésie, deux populations distinctes d'abeilles mellifères nidifiant dans des cavités ont récemment été reconnues comme deux espèces séparées, Apis cerana Fabr. et Apis nigrocincta Smith, d'après l'analyse morphométrique et les périodes de vol des mâles. L'analyse chimique des glandes mandibulaires décrite ici fournit une autre comparaison entre ces deux espèces étroitement apparentées. Chez la reine, ces glandes produisent les messages phéromonaux qui déclenchent la cour des ouvrières, attirent les mâles lors des vols d'accouplement et régulent divers aspects du fonctionnement de la colonie.
Des ouvrières et des reines fécondées des deux espèces ont été prélevées dans le centre et le nord du Sulawesi. Les têtes ont été extraites au méthanol, puis une analyse quantitative des composés suivants, sous la forme de leurs dérivés triméthylsilylés, a été effectuée par chromatographie en phase gazeuse et spectrométrie de masse : l'acide 3-hydroxy octanoïque (3-HOAA), le 4-hydroxy acétophénone, le $p$-hydroxybenzoate de méthyle (HOB), l'acide 8-hydroxy octanoïque (8-HOAA), le 4-hydroxy 3-méthoxy acétophénone, l'acide 4-hydroxy benzoïque, l'acide 3-hydroxy décanoïque (3-HDAA), le 4-hydroxy 3-méthoxyphényléthanol (HVA), l'acide (E)-9-oxo 2-décènoïque (9-ODA), l'acide $(E)$-9-hydroxy décènoïque (9-HDA), l'acide 10-hydroxy décanoïque (10-HDAA), l'alcool dihydroconiférylique, l'acide $(E)-10$-hydroxy 2-décènoïque (10-HDA), l'acide décanedioïque (C10:0 DA), l'acide dihydroférulique, l'alcool $(E)$-coniférylique, l'acide (E)-4-hydroxy cinnamique, l'acide $(E)$-2décènedioïque (C10:1 DA), et l'acide (E)-férulique. L'HVA, l'alcool dihydroconiférylique et l'alcool $(E)$-coniférylique n'ont été détectés dans aucun extrait de tête. L'HOB, le 4-hydroxy 3-méthoxyacétophénone, l'acide dihydroférulique, l'acide (E)-4-hydroxycinnamique et l'acide (E)-férulique étaient spécifiques des reines chez les deux espèces. Chez les reines, 10 des 16 composés détectés et quantifiés différaient significativement entre les espèces (Tab. I). Sur les trois composés connus de la phéromone royale des reines d'A. cerana (9-ODA, 9-HDA et HOB), le 9-HDA et l'HOB différaient significativement d'une espèce à l'autre. Chez les ouvrières, six des 11 composés détectés et quantifiés différaient significativement (Tab. II). Chez les deux types d'ouvrières d'A. nigrocincta, les nourrices et les butineuses, la plupart des composés quantifiés étaient présents en plus grandes quantités que chez $A$. cerana. Les nourrices et les butineuses différaient aussi entre elles par quelques composés (Tab. III). Les nombreuses différences observées dans 
cette analyse quantitative confirme l'hypothèse selon laquelle $A$. cerana et $A$. nigrocincta sont bien deux espèces séparées.

Apis cerana / Apis nigrocincta / glande mandibulaire / phéromone

Zusammenfassung - Analyse der Komponenten der Mandibeldrüse aus Kopfextrakten von Apis cerana und Apis nigrocincta. Zwei distinkte Populationen von höhlenbrütenden Honigbienen auf Sulawesi, Apis cerana und A. nigrocincta, wurden auf Grund von morphometrischen Analysen und unterschiedlichen Drohnenflugzeiten vor kurzem als getrennte Arten beschrieben. Die hier erfolgte chemische Analyse der Mandibeldrüsen ermöglicht einen weiteren Vergleich dieser nah verwandten Arten. Bei Königinnen erzeugt diese Drüse ein Pheromon, das zur Hofstaatbildung der Arbeiterinnen führt, die Drohnen auf dem Hochzeitsflug anlockt und noch weitere Vorgänge bei der Regulierung des Soziallebens im Bienenvolk beeinflusst.

Arbeiterinnen und begattete Königinnen beider Arten wurden in Mittel- und Nordsulawesi gesammelt. Die Köpfe wurden in Methanol extrahiert und danach wurden quantitativ mit Gaschromatographie/Massenspektrometrie die folgenden Komponenten und ihre Trimethylsilylderivate analysiert: 3-Hydroxyoctansäure (3-HOAA), 4-Hydroxyacetophenon, Methyl $p$-hydroxybenzoat (HOB), 8-Hydroxyoctansäure (8-HOAA), 4-Hydroxy-3-methoxyacetophenon, 4-Hydroxybenzoesäure, 3-Hydroxydecansäure (3-HDAA), 4-Hydroxy-3methoxyphenylethanol (HVA), (E)-9-Oxo2-decensäure (9-ODA), (E)-9-Hydroxy-2decensäure (9-HDA), 10-Hydroxydecansäure (10-HDAA), Dihydroconiferylalkohol, (E)-10-Hydroxy-2-decensäure (10-HDA), Decandiosäure (C10:0 DA), Dihydroferulasäure, $(E)$-Coniferylalkohol, (E)-4-Hydroxyzimtsäure, $(E)$-2-Decendiosäure (C10:1 DA), und (E)-Ferulasäure.
HVA, Dihydroconiferylalkohol und (E)-Coniferylalkohol wurden in keinem der Kopfextrakte nachgewiesen. HOB, 4-Hydroxy-3methoxyacetophenon, Dihydroferulasäure, $(E)$-4-Hydroxyzimtsäure, und $(E)$-Ferulasäure waren spezifisch für Königinnen beider Arten. Zwischen den Königinnenarten waren 10 der 16 nachgewiesenen und quantifizierten Komponenten signifikant verschieden (Tab. I). Bei den 3 bekannten „Hofstaatkomponenten“ des Pheromons der Mandibeldrüsen von A. cerana Königinnen (9-ODA, 9-HDA, and HOB), ergaben sich bei 9-HDA und HOB Arten signifikante Unterschiede zwischen den Arten. Bei Arbeiterinnen unterschieden sich 6 der 11 nachgewiesenen und quantifizierten Komponenten signifikant (Tab. II). Bei A. nigrocincta Arbeiterinnen waren bei Ammenund Flugbienen fast alle Komponenten in größeren Mengen vorhanden als bei A. cerana. Bei einigen Komponenten der Ammen und Sammlerinnen fanden sich ebenfalls Unterschiede (Tab. III). Die vielen nachgewiesenen Unterschiede in dieser quantitativen Analyse unterstützen die Hypothese, dass es sich bei A. cerana und A. nigrocincta wirklich um getrennte Arten handelt.

Apis cerana / Apis nigrocincta / Honigbiene / Mandibeldrüse / Pheromone

\section{REFERENCES}

Boecking O., Rosenkranz P., Sasaki M. (1999) The pore in the hard conical Apis cerana drone capping results from a spinning process, Apidologie 30, 513-519.

Crewe R.M., Velthuis H.H.W. (1980) False queens: a consequence of mandibular gland signals in worker honeybees, Naturwissenschaften 67, 467-469.

Damus M.S., Otis G.W. (1997) A morphometric analysis of Apis cerana $\mathrm{F}$. and Apis nigrocincta Smith populations from Southeast Asia, Apidologie 28, 309-323.

Engels W., Rosenkranz P., Adler A., Taghizadeh T., Lübke G., Francke W. (1997) Mandibular gland volatiles and their ontogenetic patterns in queen honey bees, Apis mellifera carnica, J. Insect Physiol. 43, 307-313. 
Fieser L.F., Fieser M. (1967) Reagents for Organic Synthesis, John Wiley and Sons, Inc., New York.

Hadisoesilo S., Otis G.W., Meixner M. (1995) Two distinct populations of cavity-nesting honey bee (Hymenoptera: Apidae) in South Sulawesi, Indonesia, J. Kans. Entomol. Soc. 68, 399-407.

Hadisoesilo S., Otis G.W. (1996) Drone flight times confirm the species status of Apis nigrocincta Smith, 1861 to be a species distinct from Apis cerana $\mathrm{F} ., 1793$, in Sulawesi, Indonesia, Apidologie 27 361-369.

Hadisoesilo S., Otis G.W. (1998) Differences in drone cappings of Apis cerana and Apis nigrocincta, J. Apic. Res. 37, 11-15.

Keeling C.I., Slessor K.N., Higo H.A., Winston M.L. (2000a) Queen Honey Bee Pheromone: New Components, 2000 Joint Annual Meeting of the Société d'entomologie du Québec, the Entomological Society of Canada, and the Entomological Society of America, Montréal, Québec, Entomological Society of America, p. 55.

Keeling C.I., Slessor K.N., Koeniger N., Koeniger G., Punchihewa R.W.K. (2000b) Quantitative analysis of the mandibular gland components of the dwarf honey bee (Apis florea Fabricius), Apidologie 31, 293-299.

Koeniger N., Koeniger G., Tingek S. (1999) Living together in harmony: the Asian bee species, Apimondia '99, XXXVI International Apicultural Congress, Vancouver, BC, Canada, p. 115.

Maa T.-C. (1953) An inquiry into the systematics of the tribus Apidini or honeybees (Hym.), Treubia 21, 525-640.

Matsuyama S., Suzuki T., Sasagawa H. (1997) Semiochemicals in the Japanese honeybee, Apis cerana japonica Rad., Zool. Sci. (Tokyo) 14 (Suppl.) 49.

Pankiw T., Winston M.L., Plettner E., Slessor K.N., Pettis J.S., Taylor O.R. (1996) Mandibular gland components of European and Africanized honey bee queens (Apis mellifera L.), J. Chem. Ecol. 22 605-615.

Plettner E. (1995) Caste-specific biosynthesis of mandibular acids in honey bees (Apis mellifera L.), Simon Fraser University, Ph.D. thesis.

Plettner E., Slessor K.N., Winston M.L., Oliver J.E. (1996) Caste-selective pheromone biosynthesis in honeybees, Science 271, 1851-1853.

Plettner E., Otis G.W., Wimalaratne P.D.C., Winston M.L., Slessor K.N., Pankiw T., Punchihewa P.W.K. (1997) Species- and caste-determined mandibular gland signals in honeybees (Apis), J. Chem. Ecol. 23, 363-377.

Plettner E., Slessor K.N., Winston M.L. (1998) Biosynthesis of mandibular acids in honey bees (Apis mellifera): De novo synthesis, route of fatty acid hydroxylation and caste selective $\beta$-oxidation, Insect Biochem. Mol. Biol. 28, 31-42.

Ruttner F. (1988) Biogeography and taxonomy of honeybees, Springer Verlag, Berlin.

Slessor K.N., Kaminski L.-A., King G.G.S., Borden J.H., Winston M.L. (1988) Semiochemical basis of the retinue response to queen honey bees, Nature 332, 354-356.

Slessor K.N., Foster L.J., Winston M.L. (1998) Royal Meer R.K., Breed M., Winston M.L., Espelie C. (Eds.), Pheromone Communication in Social Insects: Ants, Wasps, Bees and Termites, Westview Press, Boulder, Colorado, pp. 331-343.

van den Dool H., Kratz P.D. (1963) A generalization of the retention index system including linear temperature programmed gas-liquid partition chromatography, J. Chromatogr. 11, 463-471.

Winston M.L. (1987) The Biology of the Honey Bee, Harvard University Press, London.

Winston M.L., Slessor K.N. (1998) Honey bee primer pheromones and colony organization: gaps in our knowledge, Apidologie 29, 81-95. 